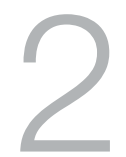

\title{
Doing away with Doba? Women's Wealth and Shifting Values in Trobriand Mortuary Distributions
}

\author{
Michelle MacCarthy
}

\section{Introduction}

The activity on the bukubaku, or centre of the hamlet, is frenzied. Throngs of women bend over giant baskets called pweia, which may stand more than a metre tall. Inside these baskets, and piled high on shallow trays made of coconut fronds called sekunona, are hundreds and hundreds of bundles of small, dry strips of banana leaves. One after another, women go to the centre of the bukubaku and call out a name, and more women, generally members of the deceased person's matrilineage, rush to throw their bundles-five here, 10 there, but always in increments of five-on the various piles. Each pile is designated as a sort of payment to those who have provided assistance to the now deceased while ill, and immediately following the death, and who are not members of the deceased's matriclan (Figure 6). At times, arguments arise over how these bundles, along with accompanying payments in colourful lengths of calico and notes and coins in kina, ${ }^{1}$ are redistributed. Despite being instigated by a death, these

1 The official state currency of Papua New Guinea (PNG). 
mortuary distributions, called sagali in the Kiriwina vernacular, ${ }^{2}$ are more festive than mournful, and are a place where women direct and control resources that they have laboured to produce, in order to demonstrate the strength of their dala (matriclan).

The scene described above represents the general atmosphere of a sagali and, in my nearly two years in Kiriwina, I saw similar scenes played out dozens and dozens of times. Such events are, as Katherine Lepani (2012: 77) says, 'dazzling to the senses' but, more importantly, they represent embodied capacity and potential and generational fecundity. The importance of banana leaf textiles $(d o b a)$ in Trobriand mortuary distributions is well documented, and has been the subject of considerable anthropological discussion (Bashkow 2011; Jolly 1992; Lepani 2012; Mosko 2000; Weiner 1974, 1976; see also Lepani this volume), though this 'sphere of exchange' (Bohannan and Bohannan 1968; Sillitoe 2006) has received far less attention, despite Annette Weiner's efforts, than kula transactions in subsequent analyses of the nature of exchange in a cross-cultural perspective. In her feminist-inspired restudy of Trobriand exchange in the 1970s, Weiner made influential contributions to anthropological theory with her examination of the importance of women's exchange practices. Banana leaf skirts and bundles, collectively referred to in the Kilivila language as doba, are produced by women from locally available materials. Of primary importance in the context of sagali are not, today, the beautiful, bright red skirts, ${ }^{3}$ which remain an essential item in preparing oneself (-katubayasi) for Trobriand traditional dance (MacCarthy 2013), but rather the bundles of scraped and dried banana leaves called nununiga. Trobriand women often refer to the buying power of nununiga as 'like your dimdim money', as they may be exchangedusually in the context of a sagali, in transactions called valova-for locally produced or externally manufactured goods (anything from a few betel nuts, a small portion of tobacco or salt, tapioca cakes and smoked fish to bubble gum, lollies or balloons [Lepani 2012: 75, 81; Weiner 1976: 78-80]). Whilst the manufacture of grass skirts is a specialised skill that

2 Tok Pisin, the pidgin language used commonly throughout much of PNG, is rarely used in the Trobriand Islands. While many educated Trobrianders speak English, the general language of communication is the vernacular language, referred to by Trobrianders as biga yakidasi (our language), and in the literature as Kiriwina or Kilivila, of which there are several mutually intelligible dialects.

3 Weiner (1976: 105-15) describes in detail the components of sagali during her fieldwork in the early 1970s, in which skirts - both in terms of the privilege of wearing the sepwana skirts (mourning skirts) and the role of skirts as prestations in the sagali distributions - appear to play a much greater role than I generally observed nearly 40 years later. 
not all Trobriand women possess, the making of banana leaf bundles is a task that defines Trobriand womanhood. To lack the skills necessary to make bundles is to be nakodana — a term that literally means 'idle or lazy woman', but also implies a lack of essential knowledge

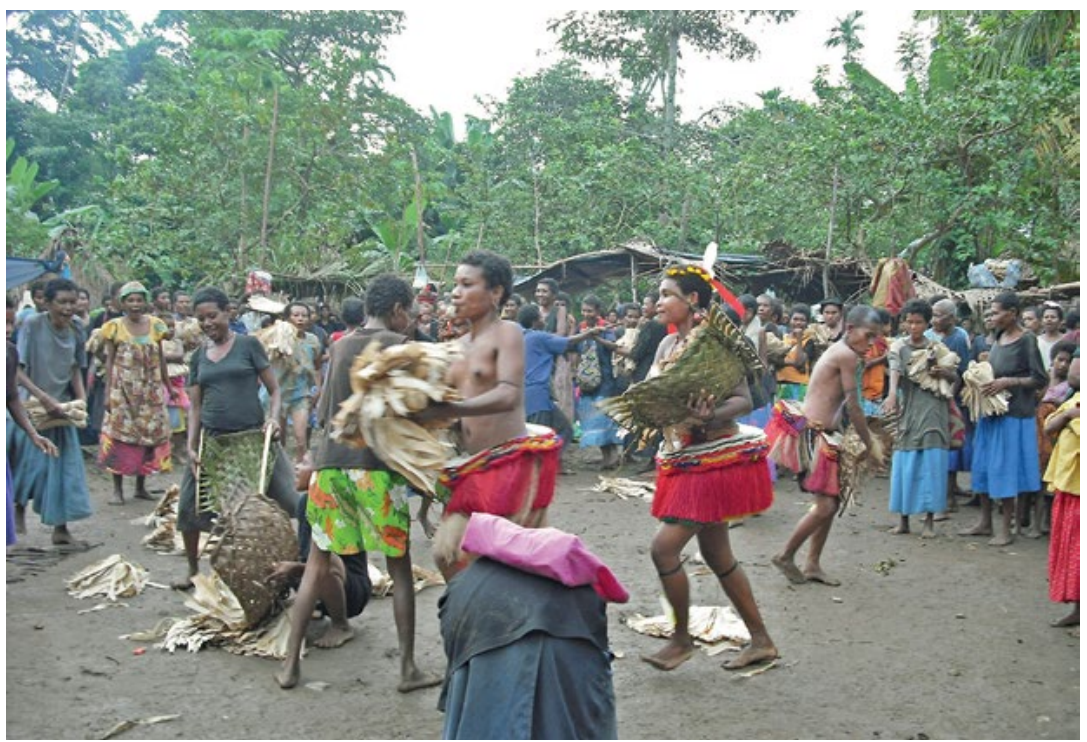

Figure 6. The frenzied activity of 'throwing' doba at sagali, Kabwaku village, Kiriwina

Source. Photographed by Michelle MacCarthy, 28 December 2009

In this chapter, I reassess the role of $d o b a$ and its production as a defining aspect of proper Trobriand womanhood, as well as being central to maintaining social relationships through its distribution at sagali. Yet in recent years, amidst pressure from the leaders of several newly established evangelical churches in the Trobriands, and a well-established trend towards a focus on (western) education and increased engagement in the cash economy, some villages are choosing to abandon the production and exchange of doba in mortuary distributions (and, indeed, to curb or cease the practice of sagali) in favour of smaller exchanges, using cash and store goods instead of the locally produced banana leaf textiles. These changes mark a shift in the conception of the value of both the time and labour necessarily expended to produce doba and the value placed on the material properties of these bundles. This shift has been the subject of much local debate in recent years, as many women—and men—argue that doba exchange is of fundamental and defining importance to Trobriand identity and kinship obligations. 


\section{Value and values}

Competing discourses are employed to justify a 'waste not, want not' attitude as espoused by the so-called 'revivalist' or evangelical churches. One argument characterises doba production as a poor use of women's time, which would be better spent in more 'productive' activity. The counter argument views doba production as constituting the unique identity of Trobriand Island women, who manufacture their own 'wealth', as well as the democratisation of labour independent of the formal economy, to which most people have limited access. I suggest that a fundamental tension lies at the base of these discourses, which is played out in various ways. On the one hand, there is a reflexive and determined effort to maintain 'culture', and the social obligations entailed therein, as part and parcel of a self-essentialised Trobriand identity looking to the past. On the other hand, there exists an equally reflexive but forward-looking discourse- 'from darkness to light'which emphasises modernity and a conscious move away from what some church officials and some Trobrianders characterise as their 'savage' past. But with revival forms of Christianity, I argue that the past becomes something to be broken from (Meyer 1998), not recirculated. What these competing discourses represent, I suggest, is a state of flux in conceptions of gendered personhood as instigated by tensions between Christianity and the ancestors, individual priorities as against inter- and intraclan obligations, and globalisation/modernity vis-à-vis regional specificity and a unique anthropological heritage. In response to this tension is a reevaluation and disjuncture in the perceived socioeconomic value of doba.

It may be useful to briefly reflect on the difference, and relatedness, of values and value. When I speak of objects having 'value', I do not, of course, mean only their use value and exchange or market value, as described by Karl Marx (1976). Instead, I refer also to less tangible, emotional ascriptions of meaning and importance, whether by individuals or communities. Chris Gregory calls value 'those invisible chains that link relations between things to relations between people' (1997: 12). David Graeber (2001: 40) asserts that value is only recognised in the eyes of another, the ascription of value rendering visible some social relationship: it is 'the way people represent the importance of their own actions to themselves' (Graeber 2001: 45). On the same lines, Michael Lambek (2013: 149) suggests that value is best understood expressly as a consequence of human activity and it circulates only through the actions of people. Values, on the other hand, might be considered as the ideal models of human behaviour, ethical ideas about virtue that are reflected in action and both individual and collective 
character (Cox and Macintyre 2014). Graeber (2001: 3), following Clyde Kluckhohn (1951: 395), points out that values are 'conceptions of the desirable', which are implicated in the choices people make about their actions - and, presumably, in how people judge both their own and others' actions. These ideas are inevitably gendered, and this is certainly true in the Trobriand case. I here invoke Louis Dumont's (1980) hierarchy of values in order to understand the relationship between the way Trobrianders value the church in relation to 'tradition' or gulagula, which might be described as the manners and customs associated with the ancestors (despite the fact that, as I shall show, the significance of $d o b a$ as an exchange valuable is far from fixed). If the church, and the more individualistic discourses it advocates with respect to production and exchange, moves higher in the hierarchy than gulagula, the result is not only a change in the orientation of values-at least for those adopting revivalist rhetoric - but also a change in how both objects and actions are assigned value (in the more economic and absolute sense). Thus, the work needed to produce doba, the act of exchanging it, and the bundles themselves as a kind of currency or means of payment lose relative value in comparison to work for cash or food crops, exchange of more 'useful' goods, and money, and industrially produced goods as objects whose value outranks doba in a more modern, forward-looking, capitalistindividualist and Christian hierarchy of values. In the process, the role of women as producers and the guardians of the matrilineage is altered. It is not, I think, foregone though, as this value transformation is far from total, and these tensions are reflected in the debates and discomforts in the local context as individuals, clans and whole villages consider or embrace the eradication of doba as a means of exchange.

\section{Gendering wealth}

In her encounter with a young, educated Trobriand man she called Joshua, Weiner (1980: 273-77) was surprised to hear the man suggest that doba was wasteful and drained resources from men. Its use, Joshua thought should be discouraged. She states:

To take away women's wealth and to alter the procedures of mortuary distributions and payments would force the most drastic changes in the status and roles of women and also in the status and roles of men. Not only would women become economically disadvantaged, but Kiriwina men would lose their base of political power [i.e. the link of yam production (men's work) and exchange to women] (Weiner 1980: 274, emphasis in original). 
Similarly, my initial instinct, upon hearing that some villages had abandoned the practice of exchanging doba, was that the declining use of 'women's wealth', as Weiner calls banana leaf textiles, would have negative implications for the power and agency of women. On the contrary, my ethnographic research ${ }^{4}$ indicates that by releasing themselves from the work of making and maintaining doba, many women have found new avenues to express their productivity and to generate new forms of wealth, such as weaving baskets that are sold in high volume at the Kiriwina airstrip. It has neither significantly reduced women's sociopolitical and economic position, nor has it altered men's base of power. Though locally generated forms of 'wealth' have in many cases been supplanted by western ones (currency and industrially manufactured goods), the extent to which such changes have fundamentally altered Trobriand social structure and gendered personhood remains somewhat ambiguous — even to Trobrianders themselves.

The sundry ceremonial transactions of Trobriand Islanders-from yams to kula shell valuables, stone axe blades and clay pots-have, of course, been a pivotal case study for theorising the nature of exchange practices cross-culturally from Bronisław Malinowski and Marcel Mauss through to the present day (e.g. Appadurai 1986; Damon 1980; Ekeh 1974; Gregory 1982, 1983; Hoenigman 2012; Jolly 1992; Leach and Leach 1983; Malinowski 1920a, 1920b, 1921; Mauss 1990; Mosko 2000; Sahlins 1965; Weiner 1974, 1976, 1980). Kula valuables are exchanged primarily in the interests of making a name for oneself, to gain status and prestige as a great 'player' of the kula game (Campbell 1983; Damon 2002; Kuehling 2005; Munn 1986). Other valuables may be exchanged alongside kula shells, but they are not the focus of exchanges. Doba (associated with women's work) and yams, clay pots ${ }^{5}$ and stone axe blades (associated with men's work) are essential exchange goods that comprise requisite 'payments' (mapula) in the wake of a death-a process that 'ensures regeneration in the cosmic realm ... The ephemeral bundles of

4 I spent approximately 18 months in 2009-10 on Kiriwina to undertake my doctoral research on cultural tourism in the Trobriands, during which time I became aware that some villages had stopped using doba. A return trip of three-and-a-half months in 2013, and a shorter visit in 2016, were undertaken as a postdoctoral fellow under the project 'Gender and Pentecostal Christianity', headed by Annelin Eriksen and funded by the Norwegian Research Council (Norges forskningsråd [NFR]) to more directly focus on this phenomenon. The ethnographic details described here reflect both periods of fieldwork, and the changes and developments noted over the eight years that I have been working in the Trobriand Islands.

5 While women may manufacture and exchange clay pots at their point of origin in the Amphlett Islands, which provides clay pots to islands like the Trobriands where clay to make such pots is lacking, in the Trobriands these valuable items are primarily exchanged by men. 
dried banana leaves are the durable material of cultural resilience and continuity' (Lepani 2012: 75). Descent in the Trobriands is matrilineal. All Trobrianders identify with one of four clans (kumila), as well as with a matriline that has a common founding ancestor (dala). Weiner has theorised the 'density' or symbolic significance of Trobriand bundles and skirts, suggesting that their importance lies less with their specific biographies or power relating to chiefly rank-as with kula valuables for example-but rather the symbolic density of doba is linked generally to the primacy of matrilineal identity (Weiner 1994: 400).

Some scholars suggest that kula is a fairly recent institution, emerging in the last 500 years or so, and that it has changed considerably in orientation and execution since European contact (Keesing 1990; Schram 2013: 7071; Van Heekeren 2014). Anecdotal evidence suggests that the same can be said for the manufacture and exchange of doba, both in terms of skirts and bundles. The brief report of a lisaladabu sagali, written by Assistant Resident Magistrate Alex Rentoul in 1929 (Bashkow 2011), makes clear that women's role in the manufacture and exchange of banana leaf bundles in mortuary distributions has a long history. However, there is evidence to suggest that, indeed, the use of doba has increased in volume over the past century. Changing technology (from shell to metal scrapers, from incising designs by hand to using carved wooden boards to quickly imprint designs) has made production of nununiga faster, and this seems to have resulted in an 'inflation' in the amount of bundles used in sagali, according to my informants (see also Weiner 1980: 276). Women told me that in the 'old days' (tukunibogwa), the baskets that were used to hold and carry the bundles (pweia) were much smaller, and that fewer bundles were exchanged. Weiner may well have arrived in the Trobriands when these textiles were in the peak of their popularity; since the mid-1980s, some villages that previously participated in these transactions began a collective movement to abolish their use, as I shall describe below. This also coincides with an increase in the use of calico, lengths of which are cut from bolts of brightly patterned Chinese-made cloth, as an essential exchange item in sagali, and women's move away from wearing grass skirts for daily apparel (as was still the case in Weiner's time) to skirts and dresses sewn of calico or second-hand clothing imported from overseas. I include this brief exegesis on the historical fluctuation in the importance and significance of doba to contextualise my own argument, demonstrating that changes in the use of doba in ceremonial transactions are not abrupt and specifically linked to Christian revival movements, but are rather a recent manifestation of a long history of adjustments to exchange practices. 


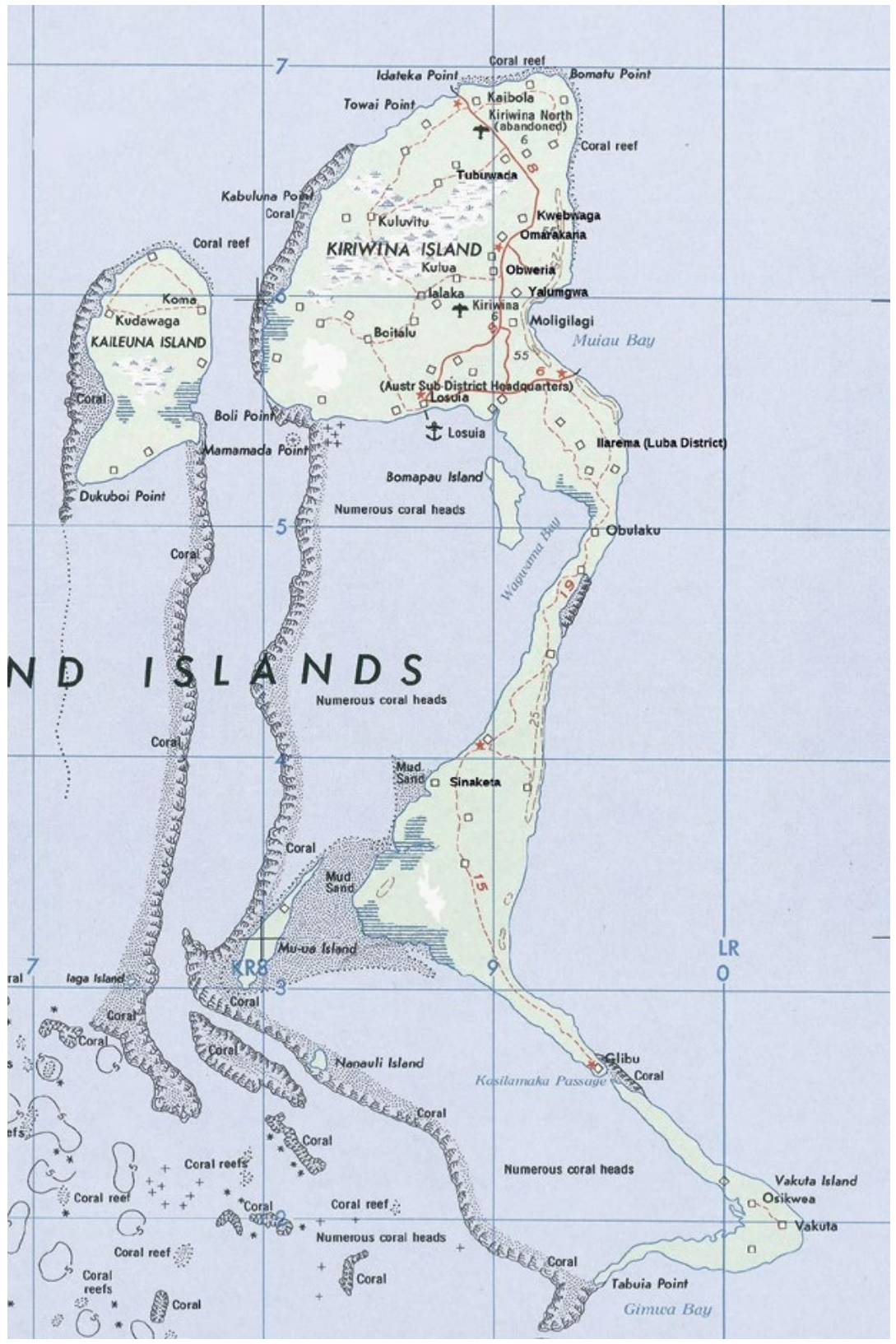

Map 1. Kiriwina, Trobriand Islands, Papua New Guinea

Source. Courtesy of the University of Texas Libraries, the University of Texas at Austin and modified by Michelle MacCarthy 


\section{Generating gendered wealth: The manufacture of doba}

Weiner's cursory description of the production of nununiga (1976, Appendix 2) does not do justice to the process. It often begins with an excursion of a group of women, all preparing for an impending sagali, who may walk several hours to areas of the island where leaves from the particular banana tree called wakaya are plentiful. This process was exemplified for me in an excursion I made with several women to the village of Ilarema, in the area called Luba (see Map 1). Departing from Yalumgwa, our village of residence, the walk took about 90 minutes. We carried with us articles of clothing, lengths of cloth and kina notes to exchange with the Luba women, who gave us bundles of fresh wakaya leaves in return. The rate of exchange was a kaupatala doba (one parcel of fresh leaves) per piece of clothing, length of cloth or two kina note. This is approximately enough leaves to make one small girl's grass skirt, or some dozens of bundles. ${ }^{6}$ In this case, the woman who organised the excursion also paid for a truck to collect the fresh leaves, and each woman who wanted to transport her haul (though not herself-the truck would be full of fresh doba, leaving no room for passengers) would pay 20 nununiga (finished bundles). While it would be possible, if strenuous, to gebila (carry on one's head) one or two of these stacks of leaves through the narrow garden paths and rough coral roads back home, more than this would be virtually impossible. The women mark their bundles, and are very concerned that each retrieves their own. The women I was with fairly ran back to their home village, in order that they would not to be too late to claim their 'raw' doba from the returned truck-they did not want to risk losing their designated piles. Having left our own village shortly after daybreak, it was dusk by the time we returned.

Once the fresh leaves are acquired, they must be scraped. Each leaf is torn into strips and, with deft, rhythmic movements, young girls, married women, divorcées and elderly widows all work to remove the outer fibres of the leaves by running a metal scraper over them. The leaves are placed one by one on a sheet of glass or, for nununiga, a carved wooden board that creates patterns on the lower third of each strip (Figure 7). One bundle of fresh leaves will take several hours to scrape. The scraped leaves are

6 When I asked women how many nununiga they could make from kaupatala ya'udila (one stack or bundle of fresh leaves), they could not give me an answer. It is highly variable, because if conditions are poor (e.g. it rains when the leaves are set out to dry) the yield will be lower, and some leaves may have defects that will render part or all of them unusable. 
soaked in water overnight, and laid out to dry in the sun in neat rows weighted down with sticks, which must be moved periodically to prevent discolouration (Figure 8). In good conditions, the leaves might be dry in two to three days; heavy rains will slow the process, and may even render the leaves unusable, negating all preceding efforts.

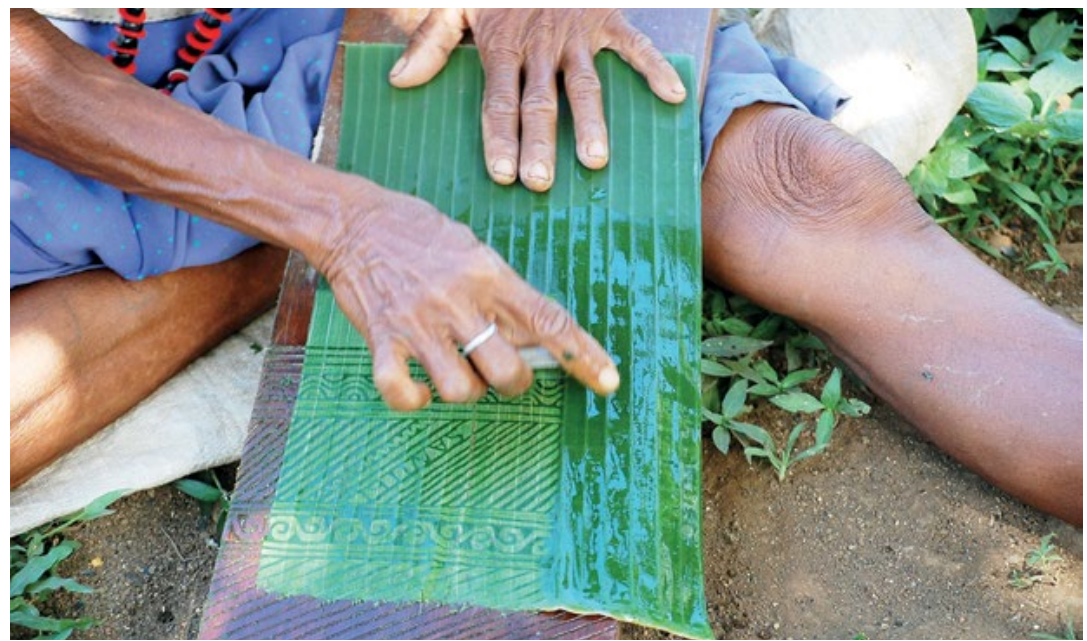

Figure 7. Fresh banana leaf scraped over carved wooden board to incise pattern, Yalumgwa village, Kiriwina

Source. Photographed by Michelle MacCarthy, 17 December 2009

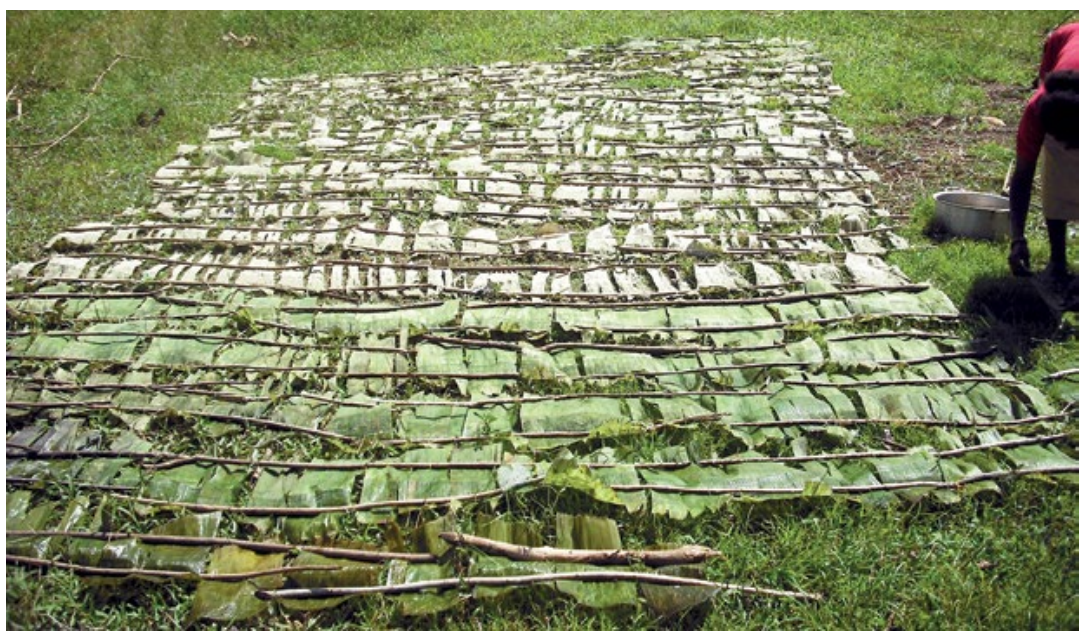

Figure 8. Freshly scraped doba leaves drying in the sun, Yalumgwa village, Kiriwina

Source. Photographed by Michelle MacCarthy, 27 July 2009 


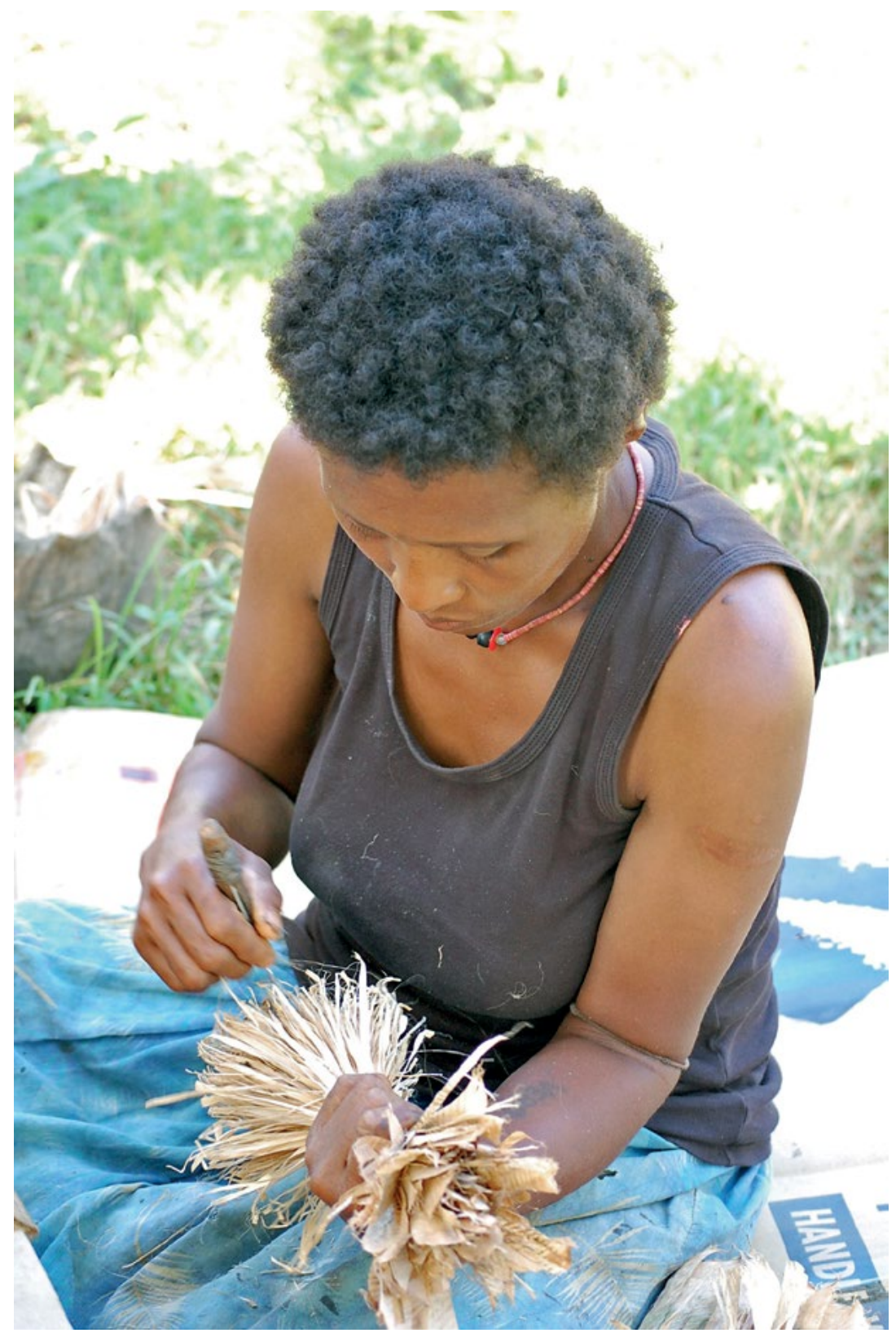

Figure 9. Veronica Matadoya making new bundles of nununiga, Yalumgwa village, Kiriwina

Source. Photographed by Michelle MacCarthy, 17 December 2009, and used with Veronica's permission 
If fine weather prevails, and the leaves dry quickly and cleanly, the making of new bundles can proceed. This task begins by recycling existing nununiga: those that have become mouldy, wet or dirty (yapupagatu) or are just too old $(y a b o g w a)$. New leaves are added to the outside, to freshen up the bundles and make them look new (yavau) and clean (yamigileu) (Figure 9). Trying to give away old, dirty nununiga as payment in sagali, or in exchange for goods in the transactions called valova (explained above) can lead to arguments and bad feelings, as well as gossip about the woman at fault. In sum, the process of making fresh doba requires many days' work, and maintaining the bundles, which are subject to rot, mould and insect and rodent predation, is a neverending task. Further, men contribute their own resources to provide their wives with items that can be exchanged for nununiga in the valova exchanges such that, as Joshua noted, 'they [women] take our [men's] money' (Weiner 1980: 274). Thus, Joshua and other Trobriand men sometimes complain that the kind of wealth they value more (cash) is inefficiently transformed into a kind of valuable, in a separate (female) sphere, which they value less. In reality, women are only concerned with acquiring doba when the death of a member of one's own (or one's father's) clan occurs, so it is not necessarily a daily preoccupation. But, in preparation for a sagali, women can work for weeks or even months to amass sufficient stores of nununiga to demonstrate the strength of her dala (matriclan) and to ensure her good name as nayo udila (a hard-working woman) and na'esaesa (woman of wealth).

\section{Changing values: Instability in banana leaves}

In Kiriwina, the largest and most densely populated of the Trobriand Islands, the bundles - along with other essential goods, both locally produced items like woven mats and store goods such as lengths of brightly patterned calico cloth, as well as coins and notes in kina-are essential exchange items that pass from clan to clan in the distributions following a death. While men and their yams, stone axe blades and clay pots also have their role to play in these exchanges, it is women's wealth and women's exchanges, as Weiner notes, that are the most visible in these complex mortuary distributions known collectively as sagali. Women gain status, respect and a good name by amassing vast quantities of bundles to give away after the death of a relative. For some urban Trobriand Islanders who return home after the death of a close relative, no amount of store-bought calico or kina notes can replace the symbolic value of nununiga to give away at sagali, and even some of the most cosmopolitan of Trobriand women will work to 
find ways of acquiring doba when they hear of a relative's death. In 2013, I was present for the sagali of a young woman of my adoptive mother's clan. The girl, and many close family members, lived in Port Moresby, but the burial and sagali were (as is the custom) held on Kiriwina. Ruth, ${ }^{7}$ who works at a hotel in the nation's capital, felt so strongly that she must have doba to throw for her niece that she sent my adoptive father off with 30 kina to valova (she deliberately refrained from using a term that would connote a straight commodity transaction) for as much doba as he could get with the cash. This is the closest I have seen to the direct purchase of doba.

The exchange of doba at sagali is essential for meeting obligations to people from other matrilineages after a death and is the means for women to demonstrate the prosperity, power and strength of their matrilineage (Weiner 1988: 117; Lepani this volume). It is thus all the more significant that there is now, in some circles, a push to eradicate the practice. Missions and the church have had a strong presence in the Trobriands for a very long time-the Methodist church arrived in 1894, Catholic missions were established in the 1930 s - but in the past 20 years or so, evangelical churches have begun to establish themselves in the islands. While not all the early churches actively discouraged women from making and exchanging doba, and those that tried were not, over the long term, very successful, in recent years evangelical churches such as Four Square, Rhema and the Christian Revival Church (CRC), as well as a few United Church leaders, have advocated that Trobriand women should stop 'wasting their time' making doba and instead focus on more so-called 'useful' activities such as church fellowship, caring for the family and striving for material and economic success.

Weiner wrote much about the economic and symbolic importance of banana leaf textiles, and the ways in which they mediated relationships between men and women (Weiner 1974, 1976, 1994; see also Hermkens 2013). Weiner stressed their stability, both in terms of the historical continuity of the volume and scale of sagali distributions (an assertion I challenged above), and in terms of their role as a 'buffer to Western economic intrusions' (1980: 276). According to Weiner's analysis, it is nearly unthinkable that doba should cease to underpin the complex distributions following a death. And yet, in several villages in Kiriwina, this is already the case-although exchanges continue, albeit in modified form.

$7 \quad$ I always asked the people with whom I did extensive work whether they preferred me to use their own name or a pseudonym if I should write about them. Their wishes have been reflected in each case. 
While I do not wish to overstate the relationship between the arrival of Pentecostal forms of Christianity and the trend in some villages towards doing away with doba, the discourses espoused by evangelical church leaders are representative of the ways in which ideas about the value of banana leaves are changing, and the moral imperatives in reorienting productive activities towards less 'wasteful' endeavours.

\section{Pentecostalism in the Trobriands}

The arrival of Pentecostalism, or Revival Christianity (Trobrianders use these terms interchangeably), in the Trobriand Islands began in the mid1980s. According to Kulaleku, the ward councillor for Kwebwaga (the first village on Kiriwina to embrace and build a Pentecostal church, and the village in which Annette Weiner was based), a need for a new and stronger faith had been locally identified in part because of the number of sorcery deaths. My informants in Kwebwaga told me that people were ready to embrace a change and bring relief to villagers who lived in fear of bwagau (black magic, sorcery). When a few Kwebwaga men went to Port Moresby, they were introduced to the CRC and Rhema churches, and felt that this 'strong' faith (peula tapwaroru) was needed back at home. An American pastor came to preach in 1986, and those suspected of being sorcerers were encouraged to pray and join the new church, and to renounce old ways. Sylvester, a Kwebwaga man, went to Bible College in Port Moresby and returned as the new CRC's first pastor in 1989. People quickly joined the new church in great numbers. Kulaleku estimates that 80-85 per cent of the village's population left the United Church to join CRC, while the current pastor of the church, Rodney, suggests that the number is over 90 per cent. This caused a rift between the two churches, but I was told that because the sorcery deaths were seen to diminish rapidly with the arrival of the new revivalist church, people believed in the efficacy of the new faith and the church remained strong. As part of their general message about the ways in which gulagula Kilivila (Trobriand custom) does not fit well with tapwaroru (Christian faith, prayer), since the late 1990s the practice of sagali has also changed in Kwebwaga. Doba plays only a small role in distributions, which have been reduced in size and scale to minimise the financial burden, as well as the time required, to work for sagali. Rodney told me, 'Isakemasi mwau okaukweda (It gives us a hard time in our households). Now, we look for school fees, for clothes for our children, instead of wasting time looking for doba' (Discussion with Rodney, 11 August 2013, Kwebwanga village). 
Once the Pentecostal churches were established on the island, there was a good deal of movement back and forth, in which people tried out the new churches, and in some cases returned to the longer-established United or Catholic congregations. Even today, marriages or disputes with church leaders can encourage people to begin attending services of a different denomination. This is not seen as problematic, since, my informants consistently told me, 'komwedodasi tadubumisa yaubada tetala' (we all believe in one God). While the Catholic Church continues to be set apart in its highly hierarchical structure and more sedate hymns and prayers, most United Churches now practice a revival form of Christianity, which is scantly differentiable from Pentecostal beliefs and styles of worship (see, for example, Van Heekeren 2014: 5; see also Gooren 2010). It is perhaps no coincidence that none of the predominately Catholic villages have made significant movements towards eradicating $d o b a,{ }^{8}$ while those villages that have are home to Pentecostal churches, 'revived' United churches or both.

\section{Women rejecting women's wealth}

Thelma, a young unmarried woman from Kwebwaga village, exemplifies the changes in attitudes and behaviour that devout Pentecostal women espouse, in direct opposition to custom. A healthy-looking girl of about 22 years of age, Thelma has a slight gap in her front teeth and, on the day I spoke with her, her hair was pinned up in braids, giving her a girlish look. While she is softly spoken and of gentle demeanour, she is all the same determined, self-assured and single-minded in her dedication to the church. She is a youth leader, and I first became aware of Thelma when I attended a CRC service in Kwebwaga, and was impressed with the power and leadership she demonstrated when leading the singalong and prayer that precedes the sermon. While most women her age are married with children, or else are on other islands or the mainland to study, Thelma told me she sees it as 'God's plan' that she should wait to marry and start a family. What is more, she has told her parents and members of her

8 While doba has not been eliminated in any Catholic villages thus far, the issue has been raised and debated within several Catholic congregations, including the village where I did the bulk of my fieldwork, Yalumgwa, as well as nearby Bawai village. Thus far, though, women have been reluctant to give up doba in these communities, and the parish priest at Wapipi (serving the northern half of Kiriwina Island Catholic parishes), who hails from Columbia and has worked in indigenous communities in South America, not only supports but participates in sagali distributions, in stark contrast to many (indigenous) leaders in the revival movement. 
community that she will not participate in sagali in any capacity, because 'sagali gala yaubada lapaisewa' (sagali is not God's work). Instead, she told me, the work she does must be to the glory of God, as she sees her future in God's hands. She says she provides 'living testimony' of how a woman can dedicate her life to God, and forego traditional obligations. She worries that 'gulagula bibiyusa tomota' (custom/tradition will pull people), and distract them from the work of God: praying, evangelising and toiling in the garden or at 'productive' tasks to give tithes and offerings to the church (Interview with Thelma, Kwebwaga village, 14 August 2013).

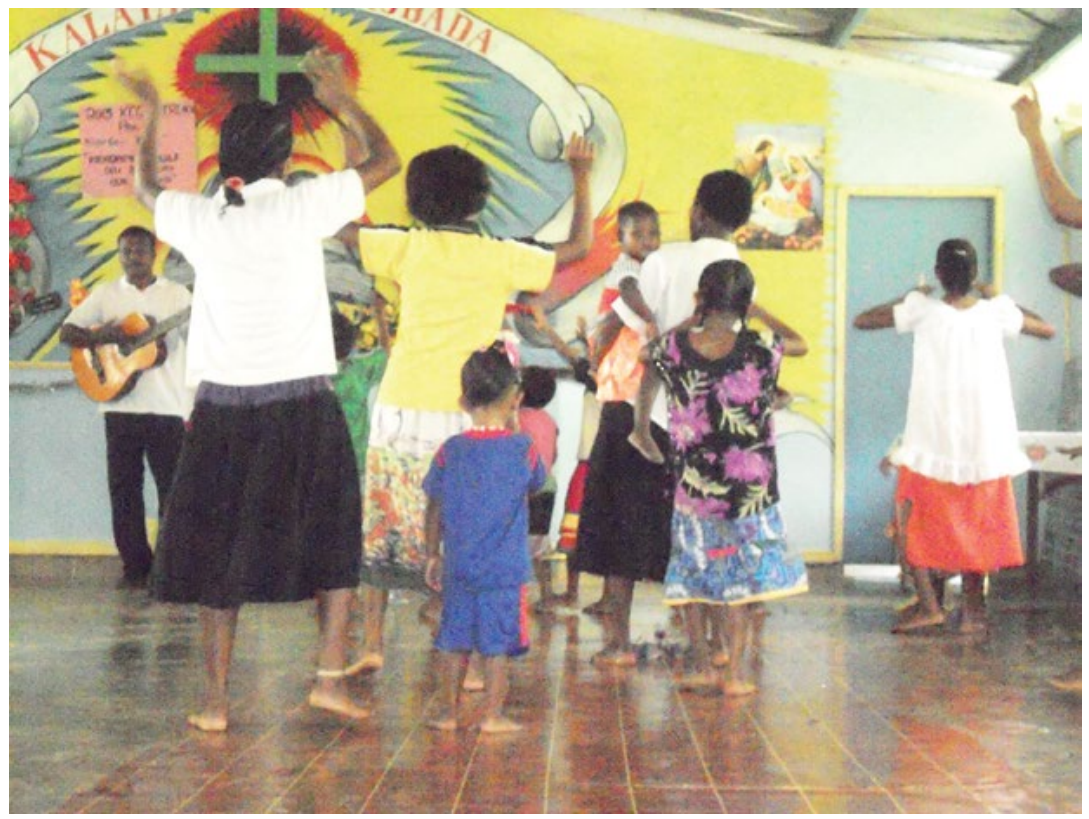

Figure 10. Singalong preceding Sunday church service at Obweria United Church, Obweria village

Source. Photographed by Michelle MacCarthy, 28 July 2013

Thelma has made a personal decision to remove herself from the obligations of sagali. In some cases, clans or villages have made collective decisions to continue to practice sagali but without using doba, only cash and store goods. Others continue to use doba but significantly reduce the scale of sagali by eradicating the huge lisaladabu distributions held six months to a year after a death, once the family and dala members have had sufficient time to amass the store of resources they will then have to give away. During my fieldwork in Kiriwina, it was brought to my attention early on that there were several villages in which a decision 
had been made (collectively, by both men and women), and was generally abided by, that women would cease production of doba and forego the complex exchanges of banana leaf textiles at sagali. Instead, they practice only a small distribution immediately following the death, using primarily kina notes (that is, cash), calico cloth and store goods, possibly with the inclusion of some woven mats. Lisaladabu, is no longer held in some villages, while others retain the spirit of lisaladabu but have replaced doba as an object of exchange entirely with calico, store goods and cash. The villages most notable for their rejection of doba are Tubuwada (and the nearby villages of Kaulikwau and Bwaitavaia, within Tubuwada Ward) in the north of Kiriwina Island; Obweria, ${ }^{9}$ to the south of Tubuwada but still in the Kilivila region; Ilarema in the middle of the island in the area called Luba; and Sinaketa in the south, in the region known as Kebwagina (see Map 1). As Map 1 makes clear, these areas are geographically dispersed across the entire island of Kiriwina. ${ }^{10}$

The people of Obweria village, which is about a 15-minute walk from my home village of Yalumgwa, have rejected the use of doba in sagali for over 20 years. Several individuals told me the story about this transformation. As early as 1994, the story goes, Darubuguyau, an old man from Obweria (one informant described him as a 'rascal fellow'), had a vision of God appear before him. God told him that Trobriand people should stop doing sagali because it was causing people to 'waste their time' in pointless endeavours. The old man explained to everyone that if they heeded God's edict, there would be no more sorcery deaths_-sorcery being the causal explanation for most deaths in Kiriwina. After his vision, Darubuguyau made a personal transformation and joined a revivalist congregation of the United Church.

When news spread about Darubuguyau's vision and subsequent conversion, the residents of Obweria agreed to cease the production, exchange and storage of doba. When I asked people why this was seen as

9 Alternatively spelled 'Obwelia' in some publications, which reflects the fact that ' $\mathrm{l}$ ' and ' $\mathrm{r}$ ' are only sometimes phonemic in Kilivila, but are sometimes interchangeable, or pronounced differently depending on dialect.

10 The other, smaller Trobriand Islands such as Kitava, Vakuta, Kaileuna, Kuyawa and Munuwata have somewhat different ways of practicing sagali, which have also changed in recent years, in some cases hand in hand with the arrival of new churches, but a full description of how practices differ on the other islands is beyond the scope of this paper. Islands such as Kitava, however, which has a very strong revival church presence, present interesting case studies in their own right. 
a good reason to change practices that had been carried out from the time of the ancestors, they explained that it was because people believed 'it was God's will'.

The broader historical context for the story of Darubuguyau's vision involves a split within the United Church in Obwelia village, which happened a decade earlier. One faction of the congregation remained associated with the mainline United Church and its regional and national hierarchy; the other faction began to practice a revivalist version of the faith (Figure 10). In the breakaway congregation, the use of guitars and tambourines was accepted and encouraged, songs were livelier, people engaged in worship more kinetically by clapping, waving arms and other actions, and the church hierarchy was less pronounced. Thus, people were already familiar with Pentecostal faith practices even before the first Pentecostal church was formally established in the village in the late 1990s, under the banner of the CRC Freedom Worship Centre (although a permanent church building was not erected until 2009). Incidentally, I was told that Darubuguyau's daughter was married to a pastor of the Rhema church, a Pentecostal denomination. The arrival of the new form of evangelical worship, and its accompanying ideals about the path to prosperity and salvation, seem to have given further impetus to the decision in Obweria to cease using doba in sagali.

When I asked women in Obweria why they had thoroughly given up the use of doba in exchanges, they told me that they had come to see the manufacture and exchange of doba as a waste of resources. They saw it as 'too time consuming, too pointless'. They said that they prefer to put efforts to more practical ends. 'We prefer to concentrate on the living, not the dead', one informant told me (13 May 2007, Obweria village). They stressed the need to focus on feeding and clothing their children, paying for school fees, and supplementing their garden food-based diet with trade store items such as rice and tinned fish. By giving up doba and the expensive practice of sagali, they were free to concentrate their resources on meeting the immediate monetary needs of the household, which they felt should be prioritised over the old practices that, to them, no longer held currency. Indeed, economic terminology predominated in these discussions, with the use of words like 'waste' and 'profit'. The emphasis, my Obweria informants told me, should be on providing for one's nuclear household rather than the extended family, and acquiring money over acquiring other forms of wealth or worrying about proficiency in performing 'traditional' Trobriand identity. The anthropology of Christianity literature is replete with examples of the increased individualism and discordant ideas of personhood that Christian 
conversion often entails (for example, Jolly, Stewart and Brewer 2012; Lutkehaus and Roscoe 2013; Robbins 2004, 2007; Tomlinson 2012). In this case, we see a second conversion from an earlier, highly syncretised Christianity, which allows greater flexibility to incorporate traditional ideas of sociality, to a second wave of conversion with far more overt discourses of modernity, prosperity and individual responsibility.

George, an erudite and well-travelled Trobriand man from Obweria village, also pointed out that Pentecostal churches discourage Trobriand women from making and wearing grass skirts, which are considered sexually provocative and hence sinful. Even those Obweria residents who have stayed as members of the United Church congregation in this village have taken up the call to abandon the practice of sagali and rarely wear the grass skirts elsewhere considered essential to doing 'proper' traditional Trobriand dance. Evoking Arjun Appadurai (1986), I argue that evangelical church preachings that discourage the use of doba (that is, both skirts and bundles), operate under an incommensurate regime of value than that espoused by those who stress the importance of so-called traditional exchange practices entailed in sagali. Ideas about 'productivity' in Pentecostal religious movements, as well as some more radical United Church factions, are fundamentally at odds with the kinds of exchanges that sagali and the mass distributions of doba represent. As one Obweria woman told me, 'Christianity is growing stronger than culture' (Mary, 13 May 2009, Obweria village).

A correlation is often made by Trobrianders between doba, in the form of bundles, and cash, as I pointed out earlier. Weiner noted this analogy as it was made to her 30 years ago (1986: 109; 1988: 120), and the same analogy was made to me by both women and men on numerous occasions. However, today, the value of nununiga relative to money is, in the eyes of some Trobriand people, slipping. For example, Steven Milamala, the pastor of the CRC in Obweria village, told me:

Doba is legal tender here. It was valued by the original Kiriwina people. They [women] put their sweat into it, they invested their resources to get it. It's good, we [in the Pentecostal church] don't say doba is demonic. But it's pupagatu [dirty]. Tomota gala bisikamsi, kikoni bimesa bikamsi, bimeyasi maena gaga [People can't wear it, rats will come and eat it, it smells bad]. And a lot of time is consumed in this process. Laplap boimeyasi dimdim [White people already brought cloth pieces], and with this we can sew it, wear it, make pillowcases, or what-not like doba. 
Doba is a waste. It's better we just switch it out with karekwa [calico cloth] (Field notes, interview with Steven Milamala in a mix of English and Kilivila, translations mine where necessary, 5 June 2013, Obweria village).

There is an echo, here, of the words spoken by Joshua, as I discussed above, who comments negatively on the way doba manipulates resources and aims them towards women's economic activities, at the expense of men who work to create wealth for their wives, mothers and sisters.

It should be noted that not all Pentecostal churches have been successful in discouraging the continued practice of sagali, and the impetus for changing exchange practices does not come from the Pentecostal churches only. It is part of a broader trend in which many people wish to lessen the obligations entailed in sagali and concentrate more time and energy on endeavours that are likely to bring monetary profit. In the hamlet of Modawosi, where I was based for my fieldwork from 2009 to 2013, the Four Square church, another Pentecostal denomination, had been very recently established-in about 2006 or 2007 . While in my section of the hamlet, fully 75 per cent of the households had left the Catholic congregation to attend the new church, there had been no consensus to move away from doba production and exchange, although the matter was discussed and debated at a community meeting (welcoming members of both the Catholic and Four Square congregations) that I attended in February 2010. While most in attendance agreed that the competitive and escalating nature of sagali was placing great economic burdens on both village residents and their wage-earning relatives in town, the idea of actually doing away with doba was an anathema to most at the meeting. While all acknowledged that now is the time of tapwaroru (church), the reasons given for maintaining the use of doba were many. Some stressed the importance of this form of wealth, which women can produce with their own labour, in helping Trobrianders to acquire things for which they would otherwise require cash to obtain. Others pointed to the need for doba as the appropriate way to thank those who have helped their relatives when they were old and sick. Still others commented on the importance of sagali for strengthening the dala or matriclan, and to ensure good relationships with affines and friends. While most felt there should be some limits on the volume of objects exchanged at sagali, most of the attendees (both men and women) saw the decision as one that should be made by the family of each dead person, rather than trying to do as Obweria village had done and make decisions that the entire community would be expected to abide by. Thus, ideas about which values should 
guide actions and, accordingly, which actions and things should be valued are in a state of flux as 'tradition' battles it out with 'modernity' - as many Trobrianders themselves see it.

\section{Conclusions: Why doba matters - and what happens if it doesn't?}

Following Mauss, in his 1938 essay 'A Category of the Human Mind: The Notion of Person; The Notion of Self' (though he was speaking of North American Indian societies), the women who in the Trobriands represent their clan can be seen to reflect the personnage: a set of names and peoples who represent the reincarnated soul of an ancestor who defines an individual's place in society and her role in rituals such as sagali. The dead person's kinswomen have a responsibility to make payments to members of other clans, as a show of both her own personal wealth and power and the strength of her matrilineage. The importance of doba in Trobriand exchange, as Weiner discusses in her 1976 monograph and in numerous articles, follows from women's importance as regenerators of their lineage. If we take a Marxian approach, the value of doba is derived from the labour of women who manufacture it. Taking a step further, we might say that when exchanged in valova, doba works as a classic commodity, while when given away at mortuary distributions, it carries many of the characteristics ascribed to the gift. As a gift, the distribution of doba is much more about the relationships between people, and the obligations both met and recreated, than it is about the bundles themselves. It does not matter if a woman manufactured the particular bundles she gives away; they are not individually inalienable in this sense. People do not speak of women who make better doba than other women, but they do commend women who amass more doba or, more specifically, who can give away the most doba at sagali. What matters is that women work to make and acquire doba (as well as other essential exchange goods), which represents their matrilineage. Thus, value itself is vested in the matrilineage. This works in much the same way, it seems to me, as men's production of yams, which likewise reflect their physical labour, their knowledge both in terms of the physical (which seeds to plant in which place at what time, when and how to thin and harvest the yams) and the supernatural (which magic spells to use, and how to perform them correctly), which are similarly used in essential reciprocal exchanges. Women, likewise, need to have the right knowledge and be able to perform the actual physical work required to produce doba (though, notably, as far as I know, magic is never used in the process of 
making it). Unlike other products of Trobriand labour, whether created by men (especially wood carvings, but also kula shells and other ornaments) or women (mostly woven handbags and sometimes mats), those that have the most dense values in obligatory exchanges at marriage and death (yams, doba) are perishable, and must constantly be regenerated. This may account for both their symbolic importance within Trobriand sociality, and for their lack of importance as objects exchanged with foreigners who cannot appreciate their symbolic weight. Thus imbued with symbolic cultural meaning as representing matrilineal identity and strength, the substitution of calico, store goods and cash should fall short (Figure 11). So, what are the implications when villages like Obweria get rid of doba? Do calico or other store-bought goods become imbued with comparable value when used in sagali, as Lepani has argued in this volume, or are they mere commodities? Perhaps both? There are conflicting moralities reflected in the sometimes disparaging, sometimes envious discourses of people in the communities that have abandoned doba in favour of lakeda tapwaroru (the way of the church), and those who cling tenaciously to the practice as essential to demonstrating the 'right' way of being a Trobriand woman who meets her exchange obligations in the 'proper' way.

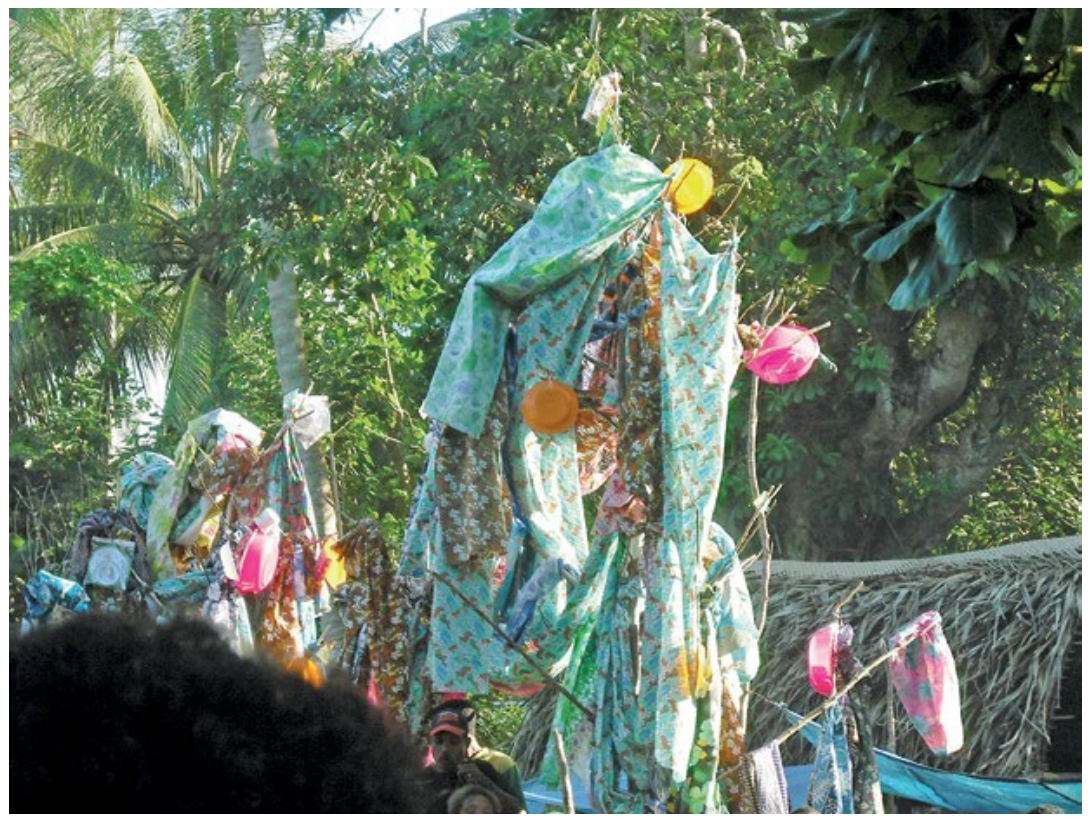

Figure 11. Sagali with calico cloth and store goods, Wapipi village, Kiriwina

Source. Photographed by Michelle MacCarthy, 30 December 2010 
Doba continues to have (at least in some villages) economic value, and can be exchanged like a commodity for goods at a set rate of exchange in valova, as I described at the beginning of this paper. However, much more importantly, it has social or symbolic value as being representative of a woman's work, knowledge and ability to reproduce the matrilineage. Without it, even when substituted by calico, cash or store goods, an important aspect of the transactions disappears. Nonetheless, for some Trobriand communities, this is the way forward; a means of becoming more 'modern', and of leading truly Godly lives. Yet for some Trobrianders of other faiths (especially Catholics), revival Christianity and the discourses about 'productivity' espoused may be viewed as an 'excuse' or way out of the hard work and time needed to acquire doba. Instead of pouring time, energy and money into sagali, women can work to make money for their families, pay their tithes and offerings to the church, contribute to school and church activities, and guarantee their place in heaven. Not all Trobrianders agree on whether doing away with doba represents a turning point in Trobriand identity and gendered personhood, or is proof that Trobriand Islanders are good Christians with their priorities in order. It is a truism that Trobrianders have long found various ways of incorporating new ideas into a cosmology that remains distinctly Trobriand; perhaps in the context of sagali, manufactured objects from soccer balls to underpants might gain density as substitutes for doba. As the process of shifting value and values away from doba continues, the enduring importance of intergenerational and wide-ranging kinship obligations remains to be seen. Neither values, nor value, are fixed, either independently or to one another.

\section{References}

Appadurai, Arjun (ed.). 1986. The Social Life of Things: Commodities in Cultural Perspective. Cambridge: Cambridge University Press.

Banton, Michael (ed.). 1965. The Relevance of Models for Social Anthropology. London: Tavistock.

Bashkow, Ira. 2011. 'Old Light on a New Controversy: Alex Rentoul's Account of the Trobriand Women's Sagali'. History of Anthropology Newsletter 38(2): 9-18. 
Bohannan, Pau and Laura Bohannan. 1968. Tiv Economy. Evanston, IL: Northwestern University Press.

Campbell, Shirley F. 1983. 'Attaining Rank: A Classification of Shell Valuables'. In The Kula: New Perspectives on Massim Exchange, ed. Jerry W. Leach and Edmund Leach, pp. 229-248. Cambridge: Cambridge University Press.

Carrier, James (ed.). 1992. History and Tradition in Melanesian Anthropology. Berkeley: University of California Press.

Cox, John and Martha Macintyre. 2014. 'Christian Marriage, Money Scams and Melanesian Social Imaginaries'. Oceania 84(2): 138-157. DOI: $10.1002 /$ ocea. 5048 .

Damon, Fred H. 1980. 'The Kula and Generalized Exchange: Considering Some Unconsidered Aspects of the Elementary Structures of Kinship'. Man (n.s.) 15(2): 267-293. DOI: 10.2307/2801671.

- 2002. 'Kula Valuables: The Problem of Value and the Production of Names'. L'Homme 162: 107-136. DOI: 10.2307/25133533.

Dumont, Louis. 1980. Homo Hierarchus: The Caste System and its Implications. Complete revised English edition. Chicago: University of Chicago Press.

Ekeh, Peter. 1974. Social Exchange Theory: The Two Traditions. Cambridge, MA: Harvard University Press.

Gooren, Henri. 2010. 'The Pentecostalization of Religion and Society in Latin America'. Exchange 39(4): 355-376. DOI: 10.1163/ $157254310 X 537025$.

Graeber, David. 2001. Toward an Anthropological Theory of Value: The False Coin of our Own Dreams. New York: Palgrave.

Gregory, Chris. 1982. Gifts and Commodities. London: Academic Press.

— 1983. 'Kula Gift Exchange and Capitalist Commodity Exchange'. In The Kula: New Perspectives on Massim Exchange, ed. Jerry W. Leach and Edmund Leach, pp. 103-117. Cambridge: Cambridge University Press. 
—— 1997. Savage Money: The Anthropology and Politics of Commodity Exchange. Amsterdam: Harwood Academic Publishers.

Hermkens, Anna-Karina. 2012. 'Becoming Mary: Marian Devotion as a Solution to Gender-based Violence in Urban PNG'. In Engendering Violence in Papua New Guinea, ed. Margaret Jolly, Christine Stewart and Carolyn Brewer, pp. 137-161. Canberra: ANU E Press. Online: press-files.anu.edu.au/downloads/press/p182671/pdf/ch04.pdf (accessed 26 January 2017).

- 2013. Engendering Objects: Dynamics of Barkcloth and Gender among the Maisin of Papua New Guinea. Leiden: Sidestone Press.

Hoenigman, Darja. 2012. 'A Battle of Languages: Spirit Possession and Changing Linguistic Ideologies in a Sepik Society, Papua New Guinea'. The Australian Journal of Anthropology 23(3): 290-317. DOI: $10.1111 /$ taja.12002.

Jolly, Margaret. 1992. 'Banana Leaf Bundles and Skirts: A Pacific Penelope's Web?' In History and Tradition in Melanesian Anthropology, ed. James Carrier, pp. 38-63. Berkeley: University of California Press.

Jolly, Margaret, Christine Stewart and Carolyn Brewer (eds). 2012. Engendering Violence in Papua New Guinea. Canberra: ANU E Press. Online: press.anu.edu.au? $\mathrm{p}=182671$ (accessed 27 June 2015).

Keesing, Roger M. 1990. 'New Lessons from Old Shells: Changing Perspectives on the Kula'. In Culture and History in the Pacific, ed. Jukka Siikala, pp. 139-163. Helsinki: the Finnish Anthropological Society.

Kluckhohn, Clyde. 1951. 'Values and Value-orientations in the Theory of Action: An Exploration in Definition and Classification'. In Towards a General Theory of Action, ed. Talcott Parsons and Edward Albert Shils, pp. 388-433. Cambridge: Harvard University Press.

Kuehling, Susanne. 2005. Dobu: The Ethics of Exchange on a Massim Island, Papua New Guinea. Honolulu: University of Hawai'i Press.

Lambek, Michael. 2013. 'The Value of (Performative) Acts'. HAU: Journal of Ethnographic Theory 3(2): 141-160. DOI: 10.14318/hau3.2.009.

Leach, Jerry W. and Edmund Leach (eds). 1983. The Kula: New Perspectives on Massim Exchange. Cambridge: Cambridge University Press. 
Lepani, Katherine. 2012. Islands of Love, Islands of Risk: Culture and HIV in the Trobriands. Nashville, TN: Vanderbilt University Press.

Lutkehaus, Nancy C. and Paul B. Roscoe (eds). 2013. Gender Rituals: Female Initiation in Melanesia. New York: Routledge.

MacCarthy, Michelle. 2013. "'More than Grass Skirts and Feathers": Negotiating Culture in the Trobriand Islands'. International Journal of Heritage Studies 19(1): 62-77. DOI: 10.1080/13527258.2011. 637946.

-2016. 'The Morality of Mweki: Performing Sexuality in the "Islands of Love"'. In Gender and Christianity in Melanesia: Towards a Unified Analysis, ed. Michelle MacCarthy and Annelin Eriksen. Special issue of The Australian Journal of Anthropology 27(2): 149-167. DOI: 10.1111/ taja.12191.

Malinowski, Bronisław. 1920a. 'The Economic Pursuits of the Trobriand Islanders'. Nature 105: 564-565. DOI:10.1038/105564a0.

- 1920b. 'Kula: The Circulating Exchanges of Valuables in the Archipelagoes of Eastern New Guinea'. Man 51: 97-105.

- 1921. 'The Primitive Economics of the Trobriand Islanders'. The Economic Journal 31(121): 1-16. DOI: 10.2307/2223283.

Marx, Karl. 1976 [1867]. Capital: A Critique of Political Economy, vol. 1, trans. B. Fowkes. London: Penguin Books.

Mauss, Marcel. 1985 [1938]. 'A Category of the Human Mind: The Notion of Person; the Notion of Self'. W.D. Halls, trans. In The Category of the Person: Anthropology, Philosophy, History, ed. Michael Carrithers, Steven Collins and Steven Lukes, pp. 1-25. Cambridge: Cambridge University Press.

Mauss, Marcel. 1990. The Gift: The Form and Reason for Exchange in Archaic Societies, trans. W.D. Halls. New York: W.W. Norton. Original edition, Essai sur le don, first published 1950 by Presses Universitaires de France en Sociologie et Anthropologie.

Meyer, Birgit. 1998. "Make a Complete Break with the Past." Memory and Post-colonial Modernity in Ghanaian Pentecostalist Discourse'. Journal of Religion in Africa 28(3): 316-349. DOI: 10.2307/1581573. 
Mosko, Mark. 2000. 'Inalienable Ethnography: Keeping-While-Giving and the Trobriand Case'. The Journal of the Royal Anthropological Institute 6(3): 377-396. DOI: 10.1111/1467-9655.00022.

Munn, Nancy. 1986. The Fame of Gawa: A Symbolic Study of Value Transformation in a Massim (Papua New Guinea) Society. Cambridge: Cambridge University Press.

Parsons, Talcott and Edward A. Shils (eds). 1951. Towards a General Theory of Action: Theoretical Foundations for the Social Sciences. Cambridge: Harvard University Press.

Robbins, Joel. 2004. Becoming Sinners: Christianity and Moral Torment in a Papua New Guinea Society. Berkeley, CA: University of California Press.

- 2007. 'Afterword: Possessive Individualism and Cultural Change in the Western Pacific'. Anthropological Forum 17(3): 299-308. DOI: $10.1080 / 00664670701637750$.

Sahlins, Marshall. 1965. 'On the Sociology of Primitive Exchange'. In The Relevance of Models for Social Anthropology, ed. Michael Banton, pp. 139-236. London: Tavistock.

Schram, Ryan. 2013. 'One Mind: Enacting the Christian Congregation among the Auhelawa, Papua New Guinea'. The Australian Journal of Anthropology 24(1): 30-47. DOI: 10.1111/taja.12019.

Siikala, Jukka (ed.). 1990. Culture and History in the Pacific. Helsinki: the Finnish Anthropological Society.

Sillitoe, Paul. 2006. 'Why Spheres of Exchange?' Ethnology 45(1): 1-23. DOI: $10.2307 / 4617561$.

Tomlinson, Matt. 2012. 'God Speaking to God: Translation and Unintelligibility at a Fijian Pentecostal Crusade'. The Australian Journal of Anthropology 23(3): 274-289. DOI: 10.1111/taja.12001.

Van Heekeren, Deborah. 2014. 'Why Alewai Village Needed a Church: Some Reflections on Christianity, Conversion, and Male Leadership in South-East Papua New Guinea'. The Australian Journal of Anthropology 25(1): 91-111. DOI: 10.1111/taja.12069. 
Weiner, Annette B. 1974. 'Women of Value: The Main Road of Exchange in Kiriwina, Trobriand Islands'. PhD thesis. Bryn Mawr College.

- 1976. Women of Value, Men of Renown: New Perspectives in Trobriand Exchange. Austin, TX: University of Texas Press.

- 1980. 'Stability in Banana Leaves: Colonialism, Economics and Trobriand Women'. In Women and Colonization: Anthropological Perspectives, ed. Mona Etienne and Eleanor Burke Leacock, pp. 270293. New York: J.F. Bergin.

—. 1986. 'Inalienable Wealth'. American Ethnologist 12(2): 178-183. DOI: 10.1525/ae.1985.12.2.02a00020.

—. 1988. The Trobrianders of Papua New Guinea. New York: Holt, Rinehart and Winston.

- 1994. 'Cultural Difference and the Density of Objects'. American Ethnologist 21(2): 391-403. DOI: 10.1525/ae.1994.21.2.02a00090. 
This text is taken from Sinuous Objects: Revaluing Women's Wealth in the Contemporary Pacific, edited by Anna-Karina Hermkens and Katherine Lepani, published 2017 by ANU Press, The Australian National University, Canberra, Australia. 